\title{
Mediastinal Teratoma
}

National Cancer Institute

\section{Source}

National Cancer Institute. Mediastinal Teratoma. NCI Thesaurus. Code C6438.

An extragonadal germ cell tumor that arises from the mediastinum. It is characterized by the presence of somatic tissues derived from two or three of the germ layers (ectoderm, endoderm, and mesoderm). 